\title{
SERVICE QUALITY OF CONVENTIONAL AND ISLAMIC BANKS IN TURKEY
}

\section{KVALITETA USLUGE KONVENCIONALNIH I ISLAMSKIH BANAKA U TURSKOJ}

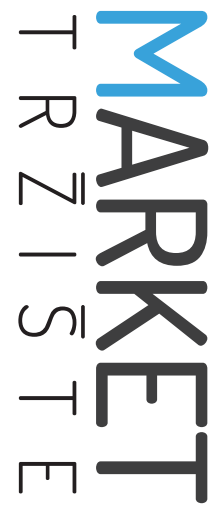

\author{
Market-Tržište \\ Vol. 33, No. 1, 2021, pp. 59-74 \\ UDK 658.56:336.71(1-69lslam)(560) \\ DOl http://dx.doi.org/10.22598/mt/2021.33.1.59 \\ Preliminary communication
}

\begin{abstract}
Özgür Kökalana , Ibrahim Güran Yumuşak ${ }^{\text {b }}$, Ahmet Bingöl ${ }^{c}$
a Istanbul Sabahattin Zaim University, Faculty of Business and Management Sciences, Inonu Cad. No. 3 Halkali / Kucukcekmece, 34303, Istanbul, TURKEY, e-mail: ozgur.kokalan@izu.edu.tr

${ }^{b}$ Istanbul Sabahattin Zaim University, Faculty of Business and Management Sciences, Inonu Cad. No. 3 Halkali / Kucukcekmece, 34303, Istanbul, TURKEY, e-mail: ibrahim.yumusak@izu.edu.tr

cIstanbul Sabahattin Zaim University, Graduate Education Institute, Inonu Cad. No. 3 Halkali / Kucukcekmece, 34303, Istanbul, TURKEY, e-mail: ahmetbin_gol@hotmail.com
\end{abstract}

\begin{abstract}
Purpose - The aim of this research study is to determine and compare the service quality of conventional and Islamic banks in Turkey.
\end{abstract}

Design/Methodology/Approach - Stratified sampling method was used to select the sample of respondents for the survey. The data collection phase was carried out online via Google forms and data obtained from 524 participants was used for the analysis. A revised SERVQUAL scale for the banking sector was employed in the research.

Findings and implications - The study found service quality expectations of bank customers to be very high, with neither bank type satisfying the expectations of their customers. While conventional banks satisfied $81.2 \%$ of their customer expectations, with that proportion falling to $77.8 \%$ in the case of Islamic banks, the perception of service quality by customers was found to be higher for conventional banks than for Islamic banks. Especially in the last 20 years, Islamic banking in Turkey has developed at an extremely fast pace. Turkey has become a highly attractive market, particularly for foreign banks focused on Islamic banking. However, although Turkey is a Muslim country, there is not a high preference for Islamic banking. The most important reason behind this

\section{Sažetak}

Svrha - Cilj je istraživanja utvrditi i usporediti kvalitetu usluge konvencionalnih i islamskih banaka u Turskoj.

Metodološki pristup - Pri odabiru uzorka korištena je metoda stratificiranog uzorkovanja. U istraživanju je uporabljena za bankarski sektor prilagođena SERVQUAL ljestvica. Prikupljanje podataka provedeno je online putem Google obrasca, a za analizu su korišteni podatci prikupljeni od 524 ispitanika.

Rezultati i implikacije - Uočeno je da su očekivanja kvalitete usluge korisnika usluga banke vrlo visoka te da obje vrste banaka ne ispunjavaju njihova očekivanja. Dok su konvencionalne banke uspjele zadovoljiti $81.2 \%$ očekivanja korisnika, kod islamskih banaka taj omjer pada na $77.8 \%$. Utvrđeno je i da je percepcija kvalitete usluge korisnika viša kod konvencionalnih nego kod islamskih banaka. U posljednjih 20 godina u Turskoj se islamsko bankarstvo vrlo brzo razvija. Turska je postala vrlo atraktivno tržište, posebno za inozemne banke usmjerene na islamsko bankarstvo. No, iako je Turska muslimanska zemlja, preferiranje islamskih banaka nije visoko. Najvažniji razlog za takvu situaciju temelji se na kvaliteti usluge koju islamske banke nude svojim korisnicima. Istraživanje je pokazalo da kvaliteta usluge banaka u Turskoj nije zadovoljavajuća, a kvalitetu usluge 
is the quality of service offered by the country's Islamic banks to their customers. This study has demonstrated that the service quality of Turkish banks is unsatisfactory and that improvements to service quality especially by Islamic banks are required, more so than for conventional banks. This research study provides companies seeking to enter the Turkish banking sector with the necessary steps to satisfy the service quality expectations of Turkish customers.

Limitations - The main limitations of this study are related to the timeframe and data collection. As service perception changes over time, the service quality of banks can be better evaluated through long-term data collection. This research focused on Turkish banks only, so its results cannot be generalized outside Turkey.

Originality - Although certain studies have investigated the service quality of banks in Turkey, no study in the literature has compared the quality of service of conventional and Islamic banks.

Keywords - service quality, SERVQUAL scale, conventional bank, Islamic bank više od konvencionalnih banaka posebno bi trebale poboljšati islamske banke. Istraživanje posebno pomaže poduzećima koja razmišljaju o ulasku na tursko bankarsko tržište da bi se vidjelo što je potrebno poduzeti za zadovoljavanje očekivanja turskih korisnika od kvalitete usluge.

Ograničenja - Glavna ograničenja istraživanja vezana su uz vremenski okvir i prikupljanje podataka. Percepcija usluge mijenja se s vremenom, tako da se kvaliteta usluge banaka može bolje ocijeniti dugotrajnijim prikupljanjem podataka. Istraživanje je ograničeno na turske banke pa su i rezultati procijenjeni samo za Tursku.

Doprinos - lako postoje prethodna istraživanja o kvaliteti usluge banaka u Turskoj, ne postoji istraživanje koje uspoređuje kvalitetu usluge konvencionalnih i islamskih banaka.

Ključne riječi - kvaliteta usluge, SERVQUAL ljestvica, konvencionalna banka, islamska banka 


\section{INTRODUCTION}

Compared to Europe, the history of modern banking in Turkey is relatively new. The main reason for this lies in the fact that interest-based banking activities were subject to a long-standing ban, motivated by religious rules, during the Ottoman Empire. After the proclamation of the republic, however, Turkey became a secular country, which led to significant changes in the Turkish banking sector. With the establishment of the Central Bank in 1930, conventional banks organized according to Western banking norms began to be established in Turkey too. Although the majority of the Turkish population were Muslim, only conventional banks operated in Turkey for nearly 50 years. The first public banking enterprise which operated on the interest-free principle was established in 1975 (Aslan \& Özdemir, 2017) and continued its activities under the name of "Participation (Islamic) Bank" after 2005. By the end of 2019, a total of 51 banks, including 44 conventional and seven Islamic banks, were operating in Turkey. Today, the share of Islamic banks in the Turkish banking sector stands at $6.5 \%$ (TBB, 2019).

At this point, it is important to investigate why Islamic banks, whose activities are governed by Islamic rules, cannot play a significant role in the banking sector of the country whose more than 99\% of the population is Muslim. This fact leads us to two important questions that have not been investigated before, namely: 1) Do conventional and Islamic banks in Turkey satisfy the service quality expectations of their customers? and 2) Is there a significant difference between the service quality of conventional and Islamic banks operating in Turkey?

Findings of the studies which explored the criteria that affect the bank selection preferences of customers point to non-faith factors related to service quality offered by the banks. The studies concluded that the non-faith factors related to bank service quality are more important than the faith factors (Rao \& Sharma, 2010; Saleh, Rahimi, Rosman \& Nani, 2013; Ltifi,
Hikkerova, Aliouat \& Gharbi, 2016; lqbal, Nisha \& Rashid, 2018; Hussain, Aslam \& Bugti, 2020). What we sought to establish is whether the results of the studies conducted in many different countries are also valid for the Turkish banking sector. So, this research study aimed to determine and compare the service quality of conventional banks and Islamic banks operating in Turkey.

In this study, the service quality of Turkish banks has been determined using the SERVQUAL scale. The SERVQUAL scale is frequently used by many researchers to determine the service quality of a business. In banking sector literature, there are many studies which have used this scale for determining the quality of bank services (Nataraajan \& Jahera Jr., 1999; McClure \& Joseph, 1999; Lewis \& Park, 2003; Rajendran \& Anantharaman, 2003; Arasli, Salime \& Katircioglu, 2005; Shanka, 2012).

Although this study was undertaken in Turkey, its results are important for both domestic and international readers and users. Turkey differs considerably from other Islamic countries. As it has had a secular system for almost a century, Turkish banks include both conventional banks based on the interest-based banking principle and Islamic banks based on the interest-free banking principle. Customers can choose either bank type according to their preferences. For this reason, compared to all other Muslim countries, Turkey is an ideal country to make a service quality comparison of the two different banking types to determine the position of Islamic banks in terms of service quality.

With Islamic banking on the rise in Turkey, as well as in the rest of the world, this trend has encouraged many investors to invest in this sector. Turkey ranks 17th worldwide by population and is a good market in terms of banking. Therefore, especially in the last twenty years, many foreign investors have made investments in the Turkish banking sector. According to the results of this research, both conventional and Islamic bank investors, who understand the service quality expectations of Turkish customers and determine the service quality according to these expec- 


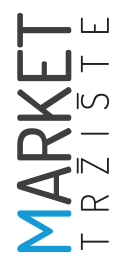

tations, are more likely to be successful in the sector. Specifically, if Islamic bank investors understand the faith-based and non-faith-based expectations of customers and develop policies that satisfy those expectations, they can be expected to be more successful in the Turkish banking sector. This study will provide information especially to these investors to help them understand the non-belief factors that can improve the service quality of Turkish customers.

There are three main parts of this study. In the literature review, the main hypotheses are formulated based on the literature on service quality. This is followed by the methodology section, which contains the data analysis based on the appropriate statistical test and a discussion of the results. The final section provides a conclusion, along with implications and recommendations for further research.

\section{LITERATURE REVIEW}

Making profit and surviving in the intensely competitive environment in which they operate are seen as the main goals by all companies worldwide. To achieve these goals, companies design their activities in different ways. Banks, which are a service business, try to achieve this basic goal by money lending and borrowing (Al-Deehani \& Aldeehani, 2017). Banks need customers to fund both their lending and borrowing activities. At this point, it is clear that the customers' criteria for bank selection are of great importance to banks. In order to attract their potential customers, banks develop many strategies. One of the most important ones is to increase the quality of the service provided.

In the literature, it is possible to find studies investigating the effect of service quality on customer satisfaction and almost all of them have found that effect to be positive (Abror et al., 2019; Alauddin, Mowla, Islam \& Hossein, 2019; Tjahjaningsih, Ningsih \& Utomo, 2020).

A review of the literature shows that similar studies have been conducted on a number of different sectors other than the banking sector. There are many studies dealing with the service quality of banks, with a large number of them examining the relationships between bank service quality and various organizational factors, such as customer loyalty and commitment, etc. (Sadek et al., 2010; Lau, Cheung, Lam \& Chu, 2013; Chochol'áková, Gab cová, Belás \& Sipko, 2015; Alshurideh, Al-Hawary, Mohammad, Al-Hawary \& Al Kurdi, 2017; Felix, 2017; Pakurár, Haddad, Nagy, Popp \& Oláh, 2019). These studies have determined that service quality has a positive effect on different organizational outcomes.

The SERVQUAL scale, which was used in most of these studies, is seen as a method of determining service quality and the effects of service quality in the banking sector (Sadek et al., 2010; Lau et al., 2013; Chochol'áková et al., 2015; Alshurideh et al., 2017; Felix, 2017; Pakurár et al., 2019). The SERVQUAL method was introduced by Parasuraman, Zeithaml, and Berry (1985) based on the gap theory which focuses on the difference between customer expectations and perceptions of a service offered by a company. Parasuraman, Zeithaml, and Berry (1988) developed a scale consisting of 22 items and five dimensions, named the SERVQUAL scale, to enable customer evaluation of a company's service quality.

Parasuraman and others (1988) determined ten basic service dimensions to measure service quality. Having obtained the results of the analysis, however, they arrived at five dimensions which are applicable to all companies, namely:

o Tangibles: all the elements required in the performance of a service, such as building, equipment, etc.;

o Reliability: the company's ability to provide the mentioned service on time, correctly, confidently, and reliably;

o Responsiveness: refers to the responsiveness of the company personnel in supporting the service receiver, providing the service promptly and sincerely, and giving the required notification directly to the receiver in a timely manner; 
- Assurance: implies that the assigned company personnel are experienced, sympathetic to the service receiver, refrain from attitudes and behaviors that may cause the service receiver to have doubts, maintain confidentiality of personal information, are capable of providing a sense of security, and refrain from behaviors that constitute an abuse of trust;

o Empathy: dimension implying that service provider companies exercise the required due diligence individually for each service beneficiary in order to meet the needs of the service requester by putting themselves in the service receiver's place.

The SERVQUAL scale was not designed for any specific sector; rather, it is accepted as a universal scale. For this reason, every service business can easily measure the quality of its service by making small changes to the scale. Although there are researchers pointing to insufficiencies of the scale and adding new dimensions to it in their studies (Avkiran, 1994; Pakurár et al., 2019), it is still widely used for measuring the service quality of companies. As of December 2020, the scale was used more than 57,000 times in different academic studies. It was used as a measurement instrument in more than 3,200 papers in 2020 alone.

An examination of the literature shows that the SERVQUAL scale is frequently used in the banking sector (Levesque \& McDougall, 1996; Jamal \& Naser 2002; Ndubisi \& Wah, 2005; Al Hawari \& Ward 2006; Kassim \& Abdulla, 2006; Amin \& Isa, 2008; Al-Wugayan, Pleshko \& Baqer, 2008; Al-Eisa \& Alhemoud 2009; Jayaraman, Shankar \& Wai, 2010; Ganguli \& Roy, 2011; Shanka, 2012; Abror et al., 2019; Asnawi, Sukoco \& Fanini, 2019). The majority of these studies aimed to determine the relationship between bank service quality and customer satisfaction. Although most of them were conducted on conventional banks (Levesque \& McDougall, 1996; Jamal \& Naser 2002; Ndubisi \& Wah, 2005; Al-Hawari \& Ward 2006; Ganguli \& Roy, 2011;
Shanka, 2012), there are also studies on Islamic banking (Kassim \& Abdulla, 2006; Amin \& Isa, 2008; Al-Wugayan et al., 2008; Al-Eisa \& Alhemoud 2009; Jayaraman et al., 2010; Abror et al., 2019; Asnawi et al., 2019).

In the literature, although the relationships between the service quality provided by banks and outcomes such as customer satisfaction and customer loyalty are frequently examined, there are also studies comparing the selection criteria of conventional banks and Islamic banks (Al-Ajmi, Abo Hussain \& Al-Saleh, 2009; Sayani \& Miniaoui, 2013; Al-Deehani \& Aldeehani, 2017). According to the results of these studies, faith factors are the most important factors influencing customers' decisions regarding bank selection. This is, however, not the case for Turkey. Although the majority of the Turkish population is Muslim, Islamic banks account for only $6.5 \%$ of the entire banking sector in Turkey and their share has not changed significantly even as new Islamic banks have been established over the past ten years. Turkey differs considerably from all other Muslim countries in the world since it has been governed as a secular country for almost a century. This affects, to a varying degree, the lives of Turkish people and the decisions they make, including financial decisions. Thus, decisions related to the choice of bank are based on non-faith factors rather than faith factors for the majority of Turkish people. Hence, it is assumed that the quality of the services provided by banks affects the customers' bank selection, so the following hypotheses have been established accordingly and analyzed in this study:

$H_{1}=$ There is a significant difference between the service quality perceptions of conventional and Islamic bank customers.

$\mathrm{H}_{2}=$ There is a significant difference between the service quality expectations and perceptions of the customers of conventional banks.

$\mathrm{H}_{3}=$ There is a significant difference between the service quality expectations and perceptions of the customers of Islamic banks.

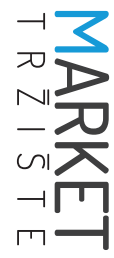

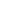




\section{METHODOLOGY}

\subsection{Sample}

The research for this study was conducted via a survey on a sample of customers using banking services in Turkey. Stratified sampling was applied to select the sample and data collection was undertaken online using Google forms. A link to the online questionnaire was sent by e-mail to the 1,000 bank users who had been selected beforehand. As a result of the sampling procedure, complete data were obtained from 524 participants and used for analysis. The data were collected over a period of three months, between September and December 2019.

\subsection{Data collection tool}

The quantitative method was used in the research survey based on the questionnaire, consisting of three parts. The first part included 8 questions aiming to determine the demographic characteristics of the participants. In the second part, these bank customers were asked what they thought the service quality of a bank should be like, or, in other words, about their expectations regarding banks in general. In the third part, they were asked to evaluate the service quality of the specific banks whose customers they were at the time. In this part, customers who relied on either a conventional or an Islamic bank filled out a single form and those who used the services of both banks filled out two forms.

The SERVQUAL scale was used to measure the expectations of customers regarding the quality of service provided to them. The first section of the model consisted of 22 variables representing the five dimensions of the scale - tangibles, reliability, responsiveness, assurance, and empathy - used to gain an understanding of their general expectations. The second section measured the quality perception of customers regarding the service provided to them, with 22 variables measuring their perception of the business providing the service. The service was considered to be of good quality if it satisfied customer expectations or exceeded them as a result of their expectations and perceptions. The service is considered to be of poor quality and the customer dissatisfied with it if the service quality perception is lower than the customer's expectations (Al-Deehani \& Aldeehani, 2017). The items were measured on a five-point Likert scale, ranging between "strongly agree" and "strongly disagree".

In the SERVQUAL scale, questions 1-4 were used to measure "tangibles", questions 5-9 "reliability", questions 10-13 "responsiveness", questions 14-17 "assurance", and questions 18-22 "empathy". The scale items used in the research are presented in the Appendix.

In the SERVQUAL scale, an expectation (E) and a perception $(P)$ point were first calculated for each statement made by each participant, after which average differences between the perception point and the expectation point were analyzed using statistical methods. The steps in the calculation process are detailed below:

\section{$S_{1}=$ tangibles dimension}

$S_{1}=\left[\left(E_{1}-P_{1}\right)+\left(E_{2}-P_{2}\right)+\left(E_{3}-P_{3}\right)+\left(E_{4}-P_{4}\right)\right] / 4$

\section{$S_{2}=$ reliability dimension}

$S_{2}=\left[\left(E_{5}-P_{5}\right)+\left(E_{6}-P_{6}\right)+\left(E_{7}-P_{7}\right)+\left(E_{8}-P_{8}\right)+\left(E_{9}-P_{9}\right)\right] / 5$

\section{$\mathrm{S}_{3}=$ responsiveness dimension}

$S_{3}=\left[\left(E_{10}-P_{10}\right)+\left(E_{11}-P_{11}\right)+\left(E_{12}-P_{12}\right)+\left(E_{13}-P_{13}\right)\right] / 4$

\section{$\mathrm{S}_{4}=$ assurance dimension}

$S_{4}=\left[\left(E_{14}-P_{14}\right)+\left(E_{15}-P_{15}\right)+\left(E_{16}-P_{16}\right)+\left(E_{17}-P_{17}\right)\right] / 4$

\section{$S_{5}=$ empathy dimension}

$\mathrm{S}_{5}=\left[\left(\mathrm{E}_{18}-\mathrm{P}_{18}\right)+\left(\mathrm{E}_{19}-\mathrm{P}_{19}\right)+\left(\mathrm{E}_{20}-\mathrm{P}_{20}\right)+\left(\mathrm{E}_{21}-\mathrm{P}_{21}\right)+\right.$ $\left.\left(E_{22}-P_{22}\right)\right] / 5$

The SERVQUAL Scale Point (SSP) was calculated as the last step and the weight of all dimensions was taken to be equal to $20 \%$. This step is indicated below:

$\mathrm{SSP}=\left[\left(\mathrm{S}_{1}+\mathrm{S}_{2}+\mathrm{S}_{3}+\mathrm{S}_{4}+\mathrm{S}_{5}\right)\right] / 5$

The SERVQUAL scale was not designed to be used for a specific service business, rather it is a 
universal scale. Therefore, certain changes should be made to the scale according to the study being conducted, especially as regards the statements provided. As the scale in this study was used to measure the service quality of banks in Turkey, the changes to it were introduced within this framework. After implementing these changes, confirmatory factor analysis (CFA) was first applied on both expectation and perception questionnaires, followed by determining the construct validity and reliability of the scale.

As a result of the CFA being applied to the SERVQUAL expectation scale, the fit indices were found to be $x^{2} / d f:$ 4.222; GFI: 0.894; AGFI: 0.836;
CFI: 0.917, and RMSEA: 0.091. In other words, the expectation scale was found to be fit for data analysis. In addition, the construct validity of the expectation scale was established. Information about the construct validity of the expectation scale is provided in Table 1.

As a result of applying the CFA applied to the SERVQUAL perception scale, the fit indices were found to be $x^{2} / d f: 4.789 ;$ GFI: 0.881; AGFI: 0.817; CFI: 0.902, and RMSEA: 0.097. The perception scale was also found to be fit and the construct validity of the scale was again established. Information about the construct validity of the perception scale is provided in Table 2.

TABLE 1: Construct validity of the SERVQUAL expectation scale

\begin{tabular}{|l|c|c|c|c|c|c|c|c|}
\cline { 2 - 9 } \multicolumn{1}{c|}{} & CR & AVE & MSV & $\begin{array}{c}\text { Tangi- } \\
\text { bles }\end{array}$ & $\begin{array}{c}\text { Reliabil- } \\
\text { ity }\end{array}$ & $\begin{array}{c}\text { Respon- } \\
\text { siveness }\end{array}$ & $\begin{array}{c}\text { Assur- } \\
\text { ance }\end{array}$ & $\begin{array}{c}\text { Empa- } \\
\text { thy }\end{array}$ \\
\hline Tangibles & 0.896 & 0.550 & 0.481 & $\mathbf{0 . 7 4 2}$ & & & & \\
\hline Reliability & 0.916 & 0.558 & 0.466 & 0.735 & $\mathbf{0 . 7 4 7}$ & & & \\
\hline Responsiveness & 0.904 & 0.527 & 0.441 & 0.516 & 0.287 & $\mathbf{0 . 7 2 6}$ & & \\
\hline Assurance & 0.890 & 0.519 & 0.478 & 0.516 & 0.287 & 0.216 & $\mathbf{0 . 7 2 1}$ & \\
\hline Empathy & 0.886 & 0.514 & 0.465 & 0.442 & 0.387 & 0.321 & 0.281 & $\mathbf{0 . 7 1 7}$ \\
\hline
\end{tabular}

$\mathrm{CR}=$ composite reliability, AVE = average variance extracted, MSV = maximum shared squared variance

TABLE 2: Construct validity of the SERVQUAL perception scale

\begin{tabular}{|l|c|c|c|c|c|c|c|c|}
\cline { 2 - 9 } \multicolumn{1}{c|}{} & CR & AVE & MSV & $\begin{array}{c}\text { Tangi- } \\
\text { bles }\end{array}$ & $\begin{array}{c}\text { Reliabil- } \\
\text { ity }\end{array}$ & $\begin{array}{c}\text { Respon- } \\
\text { siveness }\end{array}$ & $\begin{array}{c}\text { Assur- } \\
\text { ance }\end{array}$ & $\begin{array}{c}\text { Empa- } \\
\text { thy }\end{array}$ \\
\hline Tangibles & 0.914 & 0.527 & 0.462 & $\mathbf{0 . 7 2 6}$ & & & & \\
\hline Reliability & 0.908 & 0.564 & 0.432 & 0.712 & $\mathbf{0 . 7 5 1}$ & & & \\
\hline Responsiveness & 0.865 & 0.506 & 0.473 & 0.618 & 0.313 & $\mathbf{0 . 7 1 2}$ & & \\
\hline Assurance & 0.910 & 0.574 & 0.476 & 0.604 & 0.318 & 0.276 & $\mathbf{0 . 7 5 8}$ & \\
\hline Empathy & 0.897 & 0.535 & 0.496 & 0.548 & 0.404 & 0.371 & 0.281 & $\mathbf{0 . 7 3 2}$ \\
\hline
\end{tabular}

$\mathrm{CR}=$ composite reliability, AVE = average variance extracted, MSV = maximum shared squared variance

The results of the reliability analysis of the SERVQUAL scale used within the scope of this research are shown in Table 3.

According to the results of the reliability analysis, the dimensions of the SERVQUAL scale range between 0.865 and 0.916 , confirming the reliability level of the scale to be acceptable.
TABLE 3: Cronbach's alpha values for the SERVQUAL scale dimensions

\begin{tabular}{|l|c|c|}
\cline { 2 - 3 } \multicolumn{1}{c|}{} & \multicolumn{2}{c|}{ Cronbach's alpha } \\
\cline { 2 - 3 } \multicolumn{1}{c|}{} & Expectation & Perception \\
\hline Tangibles & 0.896 & 0.914 \\
\hline Reliability & 0.916 & 0.908 \\
\hline Responsiveness & 0.904 & 0.865 \\
\hline Assurance & 0.890 & 0.910 \\
\hline Empathy & 0.886 & 0.897 \\
\hline SERVQUAL scale & $\mathbf{0 . 9 0 4}$ & $\mathbf{0 . 9 1 2}$ \\
\hline
\end{tabular}




\section{FINDINGS}

\subsection{Demographic characteristics of the respondents}

In the study, 8 questions were asked to determine the demographic characteristics of the participants in the survey. Their demographic information is summarized in Table 4.

According to data in Table 4, 73.5\% of participants in this survey were male and $26.5 \%$ were female, with approximately $60 \%$ of them being married, approximately $80 \%$ younger than 45 and a significant portion of them having a high level of education. As many as $92.2 \%$ of the respondents worked for a company. The study also found that the services of Islamic banks only were used by a mere $16.2 \%$ of the participants only. Since people under the age of 18 are not a significant group in terms of banking transactions, they were not included in the research.

TABLE 4: Demographics characteristics of respondents

\begin{tabular}{|c|c|c|c|}
\hline \multirow{4}{*}{ Gender } & & Frequency & Percent \\
\hline & Male & 385 & 73.5 \\
\hline & Female & 139 & 26.5 \\
\hline & Total & 524 & 100 \\
\hline \multirow{3}{*}{ Marital status } & Married & 312 & 59.5 \\
\hline & Single & 212 & 40.5 \\
\hline & Total & 524 & 100 \\
\hline \multirow{6}{*}{ Age } & $18-25$ & 171 & 32.6 \\
\hline & $26-35$ & 135 & 25.8 \\
\hline & $36-45$ & 118 & 22.5 \\
\hline & $46-55$ & 84 & 16 \\
\hline & Over 56 & 16 & 3.1 \\
\hline & Total & 524 & 100 \\
\hline \multirow{5}{*}{ Education level } & Elementary school & 8 & 1.5 \\
\hline & High school & 75 & 14.3 \\
\hline & Undergraduate & 307 & 58.6 \\
\hline & Graduate & 134 & 25.6 \\
\hline & Total & 524 & 100 \\
\hline \multirow{3}{*}{ Employment } & Yes & 483 & 92.1 \\
\hline & No & 41 & 8.9 \\
\hline & Total & 524 & 100 \\
\hline \multirow{3}{*}{ Type of bank } & Conventional & 7 & 70.0 \\
\hline & Islamic & 3 & 30.0 \\
\hline & Total & 10 & 100 \\
\hline
\end{tabular}

\subsection{Descriptive statistics results for the SERVQUAL scale}

The first part of the analysis focused on the service quality expectations and perceptions of the participants. In this part, banks were divid- ed into two groups: conventional and Islamic banks. The results are summarized in Table 5 .

As shown in Table 5, there are significant differences between the customers' service quality perceptions of Islamic banks and conventional 
TABLE 5: SERVQUAL scores for banks' service quality expectations and perceptions

\begin{tabular}{|c|c|c|c|c|c|c|c|c|c|c|}
\hline \multirow[b]{2}{*}{ Dimension } & \multicolumn{2}{|c|}{$\begin{array}{l}\text { Customer } \\
\text { service quality } \\
\text { perception of } \\
\text { conventional } \\
\text { banks } \\
\text { (A) }\end{array}$} & \multicolumn{2}{|c|}{$\begin{array}{l}\text { Customer } \\
\text { service quality } \\
\text { perception } \\
\text { of Islamic } \\
\text { banks } \\
\text { (B) }\end{array}$} & \multicolumn{2}{|c|}{$\begin{array}{c}\text { Customer } \\
\text { service } \\
\text { quality } \\
\text { expectation } \\
\text { from a bank } \\
\text { (C) }\end{array}$} & \multicolumn{2}{|c|}{$\begin{array}{l}\text { Ratio of service } \\
\text { expectation } \\
\text { met by } \\
\text { conventional } \\
\text { banks }\end{array}$} & \multicolumn{2}{|c|}{$\begin{array}{l}\text { Ratio of service } \\
\text { expectation } \\
\text { met by Islamic } \\
\text { banks }\end{array}$} \\
\hline & Mean & $\begin{array}{l}\text { Std } \\
\text { Dev }\end{array}$ & Mean & $\begin{array}{l}\text { Std } \\
\text { Dev }\end{array}$ & Mean & $\begin{array}{l}\text { Std } \\
\text { Dev }\end{array}$ & $A-C$ & $\frac{A}{C}$ & B - C & $\frac{B}{C}$ \\
\hline Tangibles & 4.08 & 0.963 & 3.77 & 1.438 & 4.45 & 0.684 & -0.37 & $91.69 \%$ & -0.68 & $84.72 \%$ \\
\hline Reliability & 3.78 & 1.022 & 3.59 & 1.512 & 4.79 & 0.643 & -1.01 & $78.91 \%$ & -1.20 & $74.95 \%$ \\
\hline $\begin{array}{l}\text { Responsive- } \\
\text { ness }\end{array}$ & 3.61 & 1.196 & 3.54 & 1.526 & 4.71 & 0.634 & -1.10 & $76.65 \%$ & -1.17 & $75.16 \%$ \\
\hline Assurance & 3.75 & 1.112 & 3.72 & 1.490 & 4.73 & 0.648 & -0.98 & $79.28 \%$ & -1.01 & $78.65 \%$ \\
\hline Empathy & 3.71 & 1.129 & 3.52 & 1.453 & 4.65 & 0.694 & -0.94 & $79.78 \%$ & -1.13 & $75.70 \%$ \\
\hline $\begin{array}{l}\text { SERVQUAL } \\
\text { Score }\end{array}$ & 3.78 & 0.99 & 3.62 & 1.438 & 4.65 & 0.490 & -0.87 & $81.29 \%$ & -1.03 & $77.85 \%$ \\
\hline
\end{tabular}

banks. While conventional banks satisfied approximately $81.2 \%$ of their customers' service quality expectations, Islamic banks satisfied only $77.8 \%$. Both conventional and Islamic banks, therefore, failed to fully satisfy the service quality expectations of their customers. Upon examination of the sub-dimensions of the SERVQUAL scale, it was found that conventional banks mostly satisfied their customers' expectations in terms of the "tangibles" dimension of service quality (91.6\%) and at least the "responsiveness" dimension (76.6\%). In addition, Islamic banks were found to mostly satisfy the expectations of their customers regarding the "tangibles" dimension of service quality (84.7\%) and at least the "reliability" dimension (74.9\%).

In the following step, differences between the service quality perceptions of the customers of conventional and Islamic banks were analyzed using the paired samples t-test. Its results are summarized in Table 6.

TABLE 6: Comparison of service quality perceptions of conventional \& Islamic bank customers

\begin{tabular}{|l|c|c|c|c|c|c|}
\cline { 2 - 7 } \multicolumn{1}{c|}{} & $\begin{array}{c}\text { Customer } \\
\text { service quality } \\
\text { perception of } \\
\text { conventional } \\
\text { banks }\end{array}$ & $\begin{array}{c}\text { Customer } \\
\text { service } \\
\text { quality } \\
\text { perception of } \\
\text { Islamic banks }\end{array}$ & $\begin{array}{c}\text { Difference } \\
\text { between } \\
\text { expectation } \\
\text { and perception } \\
\text { means }\end{array}$ & $\begin{array}{c}\text { Std Dev of } \\
\text { the difference } \\
\text { between } \\
\text { expectation and } \\
\text { perception means }\end{array}$ & $\begin{array}{c}\text { t } \\
\text { value }\end{array}$ & $\begin{array}{c}\mathbf{p} \\
\text { value }\end{array}$ \\
\hline Tangibles & $4.08(0.96)$ & $3.77(1.43)$ & 0.31 & 0.42 & 2.721 & .000 \\
\hline Reliability & $3.78(1.02)$ & $3.59(1.51)$ & 0.19 & 0.24 & 1.632 & .022 \\
\hline $\begin{array}{l}\text { Responsive- } \\
\text { ness }\end{array}$ & $3.61(1.19)$ & $3.54(1.52)$ & 0.07 & 0.21 & 0.861 & .321 \\
\hline Assurance & $3.75(1.11)$ & $3.72(1.49)$ & 0.03 & 0.09 & 0.312 & .675 \\
\hline Empathy & $3.71(1.12)$ & $3.52(1.45)$ & 0.19 & 0.28 & 1.644 & .021 \\
\hline $\begin{array}{l}\text { SERVQUAL } \\
\text { Score }\end{array}$ & $\mathbf{3 . 7 8 ( 0 . 9 9 )}$ & $\mathbf{3 . 6 2 ( 1 . 4 3 )}$ & $\mathbf{0 . 1 6}$ & $\mathbf{0 . 2 4}$ & $\mathbf{1 . 3 2 1}$ & $\mathbf{. 0 3 2}$ \\
\hline
\end{tabular}


As shown in Table 6, there is a significant difference between the service quality perceptions of the customers of conventional and Islamic banks $(p<0.05)$. In other words, $H_{1}$ is supported. According to the test results, customers were found to have a lower service quality perception of Islamic banks. An analysis of the sub-dimensions of service quality also showed that there are no significant differences in the "responsiveness" and "assurance" dimensions.

In the following step, the difference between service quality expectations and perceptions as regards conventional banks was analyzed using the paired samples t-test, the results of which are presented briefly in Table 7.

TABLE 7: Comparison of service quality expectations and perceptions for conventional banks

\begin{tabular}{|l|c|c|c|c|c|c|}
\cline { 2 - 7 } \multicolumn{1}{c|}{} & $\begin{array}{c}\text { Expecta- } \\
\text { tion } \\
\text { mean } \\
\text { (Std Dev) }\end{array}$ & $\begin{array}{c}\text { Percep- } \\
\text { tion } \\
\text { mean } \\
\text { (Std Dev) }\end{array}$ & $\begin{array}{c}\text { Difference } \\
\text { between } \\
\text { expectation } \\
\text { and perception } \\
\text { means }\end{array}$ & $\begin{array}{c}\text { Std Dev of the } \\
\text { difference } \\
\text { between } \\
\text { expectation and } \\
\text { perception means }\end{array}$ & $\begin{array}{c}\text { t } \\
\text { value }\end{array}$ & $\begin{array}{c}\mathbf{p} \\
\text { value }\end{array}$ \\
\hline Tangibles & $4.45(0.68)$ & $4.08(0.96)$ & 0.37 & 0.76 & 7.321 & .000 \\
\hline Reliability & $4.79(0.64)$ & $3.78(1.02)$ & 1.01 & 1.02 & 11.302 & .000 \\
\hline $\begin{array}{l}\text { Responsive- } \\
\text { ness }\end{array}$ & $4.71(0.63)$ & $3.61(1.19)$ & 1.10 & 1.12 & 12.122 & .000 \\
\hline Assurance & $4.73(0.64)$ & $3.75(1.11)$ & 0.98 & 1.04 & 11.641 & .000 \\
\hline Empathy & $4.65(0.69)$ & $3.71(1.12)$ & 0.94 & 0.98 & 8.756 & .000 \\
\hline $\begin{array}{l}\text { SERVQUAL } \\
\text { Score }\end{array}$ & $\mathbf{4 . 6 5 ( \mathbf { 0 . 4 9 ) }}$ & $\mathbf{3 . 7 8 ( 0 . 9 9 )}$ & $\mathbf{0 . 8 7}$ & $\mathbf{0 . 8 1}$ & $\mathbf{7 . 9 6 7}$ & $\mathbf{. 0 0 0}$ \\
\hline
\end{tabular}

As indicated in Table 7, the service quality expectations of the customers using only the services of conventional banks were found to be high and not significantly satisfied by the conventional banks $(p<0.05)$. Therefore, $H_{2}$ is supported.
Table 8 presents an analysis of the difference between service quality expectations and perceptions of the customers of Islamic banks.

TABLE 8: Comparison of service quality expectations and perceptions for Islamic banks

\begin{tabular}{|c|c|c|c|c|c|c|}
\hline & $\begin{array}{c}\text { Expecta- } \\
\text { tion mean } \\
\text { (Std Dev) }\end{array}$ & $\begin{array}{c}\text { Percep- } \\
\text { tion mean } \\
\text { (Std Dev) }\end{array}$ & $\begin{array}{c}\text { Difference } \\
\text { between } \\
\text { expectation } \\
\text { and perception } \\
\text { means }\end{array}$ & $\begin{array}{c}\text { Std Dev of } \\
\text { the difference } \\
\text { between } \\
\text { expectation and } \\
\text { perception means }\end{array}$ & $\begin{array}{c}\text { t } \\
\text { value }\end{array}$ & $\begin{array}{c}\mathbf{p} \\
\text { value }\end{array}$ \\
\hline Tangibles & $4.45(0.68)$ & $3.77(1.43)$ & 0.68 & 0.78 & 7.534 & .000 \\
\hline Reliability & $4.79(0.64)$ & $3.59(1.51)$ & 1.20 & 1.29 & 13.978 & .000 \\
\hline $\begin{array}{l}\text { Responsive- } \\
\text { ness }\end{array}$ & $4.71(0.63)$ & $3.54(1.52)$ & 1.17 & 1.23 & 13.452 & .000 \\
\hline Assurance & $4.73(0.64)$ & $3.72(1.49)$ & 1.01 & 1.09 & 11.204 & .000 \\
\hline Empathy & $4.65(0.69)$ & $3.52(1.45)$ & 1.13 & 1.12 & 12.397 & .000 \\
\hline $\begin{array}{l}\text { SERVQUAL } \\
\text { Score }\end{array}$ & $4.65(0.49)$ & $3.62(1.43)$ & 1.03 & 1.01 & 11.512 & .000 \\
\hline
\end{tabular}


As indicated in Table 8, the service quality expectations of Islamic bank customers were found to be very high and not significantly satisfied by the Islamic banks $(p<0.05) . H_{3}$ is, therefore, supported.

\section{CONCLUSION AND DISCUSSION}

The majority of the Turkish population is Muslim. However, compared to other Muslim countries, Turkey differs considerably because it has had secularist governments for almost a century. It is possible to see this difference reflected in the lives of the Turkish people. Although the majority of the population is Muslim, they prioritize non-faith factors over faith factors in their financial decisions. Bank selection can be seen as one of such decisions.

In Turkey, there are two type of banks: conventional banks operating according to non-faith factors and Islamic banks operating according to Islamic faith factors. Conventional banks have been found to dominate the banking sector even despite the Muslim majority in the overall population of the country. This study tried to explore the reasons for the dominance of conventional banks through the differences in their service quality against the quality of services provided of Islamic banks. Accordingly, we aimed to determine and compare the service quality of the conventional and Islamic banks operating in Turkey. To measure the service quality of banks, the SERVQUAL scale containing five dimensions called "tangible", "reliability", "responsiveness", "assurance", and "empathy" was used with minor changes.

Based on the data analysis, it was established that conventional banks satisfied approximately $81.2 \%$ of their customers' service quality expectations, while Islamic banks satisfied only $77.8 \%$. Both conventional and Islamic banks, therefore, did not fully satisfy the service quality expectations of their customers. According to the results, customers were more satisfied with the services provided by conventional banks. An analysis of the sub-dimensions of service quality showed that the customers found conventional banks to be more satisfactory than Islamic banks when it came to the "tangibles", "empathy", and "reliability" dimensions. When it comes to the other dimensions, the satisfaction levels for the two types of banks were found to be almost the same. In short, it can be concluded that the service quality perception of bank customers in Turkey is higher in the case of conventional banks, which explains why this bank type dominates the market. Although conventional banks were seen as better than Islamic banks in terms of service quality, it was found that neither bank type can fully satisfy the service quality expectations of their customers. Therefore, they need to take steps to increase their service quality.

The results of this study are highly beneficial for managers working at conventional and Islamic bank, as well as for investors. Namely, they show that:

o The banks should increase the supply of equipment provided for customer use, pay more attention to the physical appearance of their personnel, modernize bank equipment and ensure the availability of the equipment (ATM, online services, etc.) by providing continuous maintenance and updates.

o The most important factor found as a result of this study is the reliability of the banks. For this reason, it is required of the bank personnel and directors to be more active and responsive in providing the necessary services they committed themselves to provide and assure the customers about their reliability.

o Customer feedback is moderately important. When it comes to requests and made by customers to the bank directors and the bank personnel as well as their complaints, approaching customers with a willingness to help will make them loyal to the bank and encourage them to keep using the bank's services.

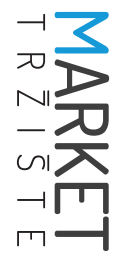


o Customers are more pleased when the bank personnel are polite, have more information to share and experience about the work performed, and when they approach the customer with a higher level of empathy.

- In certain aspects, institutions providing Islamic banking services can benefit from institutions providing conventional banking services because, as can be seen from the results of the research conducted, customer perceptions of the service quality of conventional banks are higher than for Islamic banks.

- Investors should take the necessary actions to satisfy service quality expectations of customers too. Particularly investors who are willing to invest in Islamic banking in Turkey should simultaneously provide faith and non-faith factors to customers to increase their satisfaction level. If they are successful in this respect, their banks will probably be more successful than conventional banks.

Since the SERVQUAL scale was not designed for a specific service business, sometimes it may not adequately measure service quality for certain types of businesses. While there have been studies recognizing this deficiency and trying to correct it, no scale that has been agreed upon and is more widely used than the SERVQUAL has yet been developed. This problem could be ad- dressed through a study aimed at developing either a new scale that would be more comprehensive than the SERVQUAL scale or different service quality scales that can be developed for service businesses with different characteristics.

In future studies researcher could do some of the following:

o It would be useful to develop a widely used service quality scale for banks.

- For both conventional and Islamic banks in Turkey, extensive comparative research can be conducted across diverse organizational outcomes such as customer satisfaction, customer loyalty, etc.

- Studies can be carried out for the purpose of comparing the service quality of banks operating in Turkey and other countries.

- Multinational and more comprehensive studies can be conducted on the service quality of Islamic banks, which is rated somewhat lower than that of conventional banks.

The main limitations of this study are related to the timeframe and data collection. As service perception changes over time, the service quality of banks can be better evaluated through data collection over a longer term. This research study focuses strictly on Turkish banks, so its results are also applicable only to Turkey.

\section{References}

1. Abror, A., Patrisia, D., Engriani, Y., Evanita, S., Yasri, Y., \& Dastgir, S. (2019). Service Quality, Religiosity, Customer Satisfaction, Customer Engagement and Islamic Bank's Customer Loyalty. Journal of Islamic Marketing, 11(6), 1691-1705.

2. Al-Ajmi, J., Abo Hussain, H., \& Al-Saleh, N. (2009). Clients of Conventional and Islamic Banks in Bahrain: How They Choose Which Bank to Patronize. International Journal of Social Economics, 36(11), 1086-1112.

3. Alauddin, S. H. A., Mowla, M. M., Islam, M. M., \& Hossein, M. M. (2019). Investigating the Relationship Between Service Quality, Customer Satisfaction and Customer Loyalty in Hotel Industry: Bangladesh Perspective. Global Journal of Management and Business Research, 19(1), 1-8.

4. Al-Deehani, M. T. \& Aldeehani, M. T. (2017). Perceptions and Predictions of Service Quality-Customer Satisfaction of Conventional and Islamic Banks in The GCC Region. Journal of Research in Business, Economics and Management, 9(1), 1641-1656. 
5. Al-Eisa, A., \& Alhemoud, A. (2009). Using A Multiple-Attribute Approach for Measuring Customer Satisfaction with Retail Banking Services in Kuwait. International Journal of Bank Marketing, 27(4), 294-314.

6. Al-Hawari, M., \& Ward, T. (2006). The Effect of Automated Service Quality on Australian Banks' Financial Performance and The Mediating Role of Customer Satisfaction. Marketing Intelligence \& Planning, 24(2), 127-147.

7. Alshurideh, M. T., Al-Hawary, S. I. S., Mohammad, A. M. E., Al-Hawary, A. A., \& Al Kurdi, B. H. (2017). The Impact of Islamic Banks' Service Quality Perception on Jordanian Customers Loyalty. Journal of Management Research, 9, 139-159.

8. Al-Wugayan, A., Pleshko, L., \& Baqer, S. (2008). An Investigation of The Relationships Among Consumer Satisfaction, Loyalty, and Market Share in Kuwaiti Loan Services. Journal of Financial Services Marketing, 13(2), 95-106.

9. Amin, M., \& Isa, Z. (2008). An Examination of The Relationship Between Service Quality Perception and Customer Satisfaction: A SEM Approach Towards Malaysian Islamic Banking. International Journal of Islamic and Middle Eastern Finance and Management, 1(3), 191-209.

10. Arasli, H., Salime M. S., \& Katircioglu, S. T. (2005). Customer Service Quality in The Greek Cypriot Banking Industry. Managing Service Quality: An International Journal, 15(1), 41-56.

11. Aslan, H., \& Özdemir, M. (2017). Türkiye'de İslami Finansın Dönüşümünün Ekonomi Politiği, Ankara: SETA/Siyaset, Ekonomi ve Toplum Araştırmaları Vakfı.

12. Asnawi, N., Sukoco, B. M., \& Fanani, M. A. (2019). The Role of Service Quality Within Indonesian Customers Satisfaction and Loyalty and Its Impact on Islamic Banks. Journal of Islamic Marketing, $11(1), 192-212$.

13. Avkiran, N. K. (1994). Developing an Instrument to Measure Customer Service Quality in Branchbanking. International Journal of Bank Marketing, 12(6), 10-18.

14. Chochol'áková, A., Gab cová, L., Belás, J., \& Sipko, J. (2015). Bank Customers' Satisfaction, Customers' Loyalty and Additional Purchases of Banking Products and Services. A Case Study from The Czech Republic. Economics \& Sociology, 8, 82-94.

15. Felix, R. (2017). Service Quality and Customer Satisfaction in Selected Banks in Rwanda. Journal of Business and Financial Affairs, 6, 246-256.

16. Ganguli, S., \& Roy, S. K. (2011). Generic Technology-Based Service Quality Dimensions in Banking: Impact on customer Satisfaction and Loyalty. International Journal of Bank Marketing, 29(2), 168-189.

17. Hussain, A., Aslam, H. D., \& Bugti, F. (2020). A Study on Bank Selection Criteria and Retail Customers' Satisfaction Across Islamic Banks in Pakistan. Al-Qalam, 25(1), 312-341.

18. Iqbal, M., Nisha, N., \& Rashid, M. (2018). Bank Selection Criteria and Satisfaction of Retail Customers of Islamic Banks in Bangladesh. International Journal of Bank Marketing, 36(5), 931-946.

19. Jamal, A., \& Naser, N. (2002). Customer Satisfaction and Retail Banking: An Assessment of Some of The Key Antecedents of Customer Satisfaction in Retail Banking. International Journal of Bank Marketing, 20(4), 146-160.

20. Jayaraman, M., Shankar, C., \& Wai, M. (2010). Service Quality Delivery and Its Impact on Customer Satisfaction in The Banking Sector in Malaysia. International Journal of Innovation, Management and Technology, 1(4), 398-404.

21. Kassim, N., \& Abdulla, A. (2006). The Influence of Attraction on Internet Banking: An Extension to The Trust Relationship Commitment Model. International Journal of Bank Marketing, 24(6), 424-442.

22. Lau, M. M., Cheung, R., Lam, A. Y., \& Chu, Y. T. (2013). Measuring Service Quality in The Banking Industry: A Hong Kong Based Study. Contemporary Management Research, 9, 263-282.

23. Levesque, T., \& McDougall, G. (1996). Determinants of Customer Satisfaction in Retail Banking. International Journal of Bank Marketing, 14(7), 12-20. 
24. Lewis, B. R., \& Park, W. (2003). Service Quality Measurement in The Banking Sector in South Korea. International Journal of Bank Marketing, 21(4), 191-201.

25. Ltifi, M., Hikkerova, L., Aliouat, B., \& Gharbi, J. (2016). The Determinants of The Choice of Islamic Banks in Tunisia. International Journal of Bank Marketing, 34(5), 710-730.

26. McClure, C., \& Joseph, B. (1999). Service Quality in The Banking Sector: The Impact of Technology on Service Delivery. International Journal of Bank Marketing, 17(4), 182-193.

27. Nataraajan, R., \& Jahera Jr., J. S. (1999). Service Quality in The Banking Industry: An Assessment in A Developing Economy. International Journal of Bank Marketing, 17(3), 116-125.

28. Ndubisi, N., \& Wah, C. K. (2005). Factorial and Discriminant Analyses of The Underpinnings of Relationship Marketing and Customer Satisfaction. International Journal of Bank Marketing, 23(7), 542-557.

29. Pakurár, M., Haddad, H., Nagy, J., Popp, J., \& Oláh, J. (2019). The Service Quality Dimensions That Affect Customer Satisfaction in The Jordanian Banking Sector. Sustainability, 11, 1-24.

30. Parasuraman, A., Ziethaml, V., \& Berry, L. L. (1985). A Conceptual Model of Service Quality and Its Implications for Future Research. Journal of Marketing, 49(3), 41-50.

31. Parasuraman, A., Ziethaml, V., \& Berry, L. L. (1988). SERVQUAL: A Multiple-item Scale for Measuring Consumer Perceptions of Service Quality. Journal of Retailing, 62(1), 12-40.

32. Rajendran, C., \& Anantharaman, R. N. (2003). Customer Perceptions of Service Quality in The Banking Sector of a Developing Economy: A Critical Analysis. International Journal of Bank Marketing, 21(5), 233-242.

33. Rao, S., \& Sharma, D. R. (2010). Bank Selection Criteria Employed by MBA Students in Delhi: An Empirical Analysis. Journal of Business Studies Quarterly, 1(2), 56-69.

34. Sadek, D. M., Zainal, N. S., Taher, M. S. I. M., Yahya, A. F., Shaharudin, M. R., Noordin, N., Zakaria, Z., \& Jusoff, K. (2010). Service Quality Perceptions Between Cooperative and Islamic Banks of Britain. American Journal of Economics and Business Administration, 2(1), 1-5.

35. Saleh, M. S. M, Rahimi, M., Rosman, M., \& Nani, N. K. (2013). Bank Selection Criteria in A Customers' Perspective. Journal of Business and Management, 7(6), 15-20.

36. Sayani, H., \& Miniaoui, H. (2013). Determinants of Bank Selection in The United Arab Emirates. International Journal of Bank Marketing, 31(3), 206-228.

37. Shanka, M. S. (2012). Bank Service Quality, Customer Satisfaction and Loyalty in Ethiopian Banking Sector. Journal of Business Administration and Management Sciences Research, 1(1), 1-9.

38. Türkiye Bankalar Birliği - TBB (2019). available at https://www.tbb.org.tr/modules/banka-bilgileri/ banka_Listesi.asp?tarih=15/1/2019 (accessed January 16 $6^{\text {th }}, 2019$ ).

39. Tjahjaningsih, E., Ningsih, D. U. E., \& Utomo, A. P. (2020). The Effect of Service Quality and Product Diversity on Customer Loyalty: The Role of Customer Satisfaction and Word of Mouth. Journal of Asian Finance, Economics and Business, 7(12), 481-490. 


\section{APPENDIX}

\section{The SERVQUAL Expectation Scale}

\begin{tabular}{|c|c|c|}
\hline \multirow{4}{*}{ Tangibles } & E1 & $\begin{array}{l}\text { A perfect bank should have modern equipment and efficient online } \\
\text { banking. }\end{array}$ \\
\hline & E2 & $\begin{array}{l}\text { Physical facilities and online banking of a perfect bank should be } \\
\text { visually appealing. }\end{array}$ \\
\hline & E3 & $\begin{array}{l}\text { The employees of a perfect bank should be well-dressed and neat in } \\
\text { their appearance. }\end{array}$ \\
\hline & E4 & $\begin{array}{l}\text { The appearance of the physical facilities of a perfect bank should be } \\
\text { in keeping with the type of services provided. }\end{array}$ \\
\hline \multirow{5}{*}{ Reliability } & E5 & $\begin{array}{l}\text { When a perfect bank promises to do something by a certain time, it } \\
\text { should do so. }\end{array}$ \\
\hline & E6 & $\begin{array}{l}\text { When customers have problems, a perfect bank should be } \\
\text { sympathetic and reassuring. }\end{array}$ \\
\hline & E7 & A perfect bank should be dependable. \\
\hline & E8 & $\begin{array}{l}\text { A perfect bank should provide its services at the time promised to do } \\
\text { so. }\end{array}$ \\
\hline & E9 & A perfect bank should keep its records accurately. \\
\hline \multirow{4}{*}{ Responsiveness } & E10 & $\begin{array}{l}\text { A perfect bank should be expected to tell customers exactly when } \\
\text { services will be performed. }\end{array}$ \\
\hline & E11 & $\begin{array}{l}\text { The employees of a perfect bank should realistically be expected to } \\
\text { give prompt service to customers. }\end{array}$ \\
\hline & E12 & $\begin{array}{l}\text { The employees of a perfect bank always have to be willing to help } \\
\text { customers. }\end{array}$ \\
\hline & E13 & $\begin{array}{l}\text { It should be okay for a perfect bank to respond to customer requests } \\
\text { promptly even if it is too busy. }\end{array}$ \\
\hline \multirow{4}{*}{ Assurance } & E14 & Customers should be able to trust the employees of a perfect bank. \\
\hline & E15 & $\begin{array}{l}\text { Customers should be able to feel safe in their transactions with a } \\
\text { perfect bank's employees. }\end{array}$ \\
\hline & E16 & The employees of a perfect bank should be polite. \\
\hline & E17 & $\begin{array}{l}\text { The employees of a perfect bank should get adequate support from } \\
\text { the bank to do their jobs well. }\end{array}$ \\
\hline \multirow{5}{*}{ Empathy } & E18 & $\begin{array}{l}\text { A perfect bank should be expected to give customers individual } \\
\text { attention. }\end{array}$ \\
\hline & E19 & $\begin{array}{l}\text { A perfect bank is expected to have employees who give customers } \\
\text { personal service. }\end{array}$ \\
\hline & E20 & $\begin{array}{l}\text { The employees of a perfect bank should realistically be expected to } \\
\text { know the specific needs of its customers. }\end{array}$ \\
\hline & E21 & $\begin{array}{l}\text { A perfect bank should realistically be expected to have its customers' } \\
\text { best interests at heart. }\end{array}$ \\
\hline & E22 & $\begin{array}{l}\text { A perfect bank should be expected to have operating hours that are } \\
\text { convenient to all its customers. }\end{array}$ \\
\hline
\end{tabular}




\section{The SERVQUAL Perception Scale}

\begin{tabular}{|c|c|c|}
\hline \multirow{4}{*}{ Tangibles } & P1 & The bank I use has modern equipment and efficient online banking. \\
\hline & P2 & $\begin{array}{l}\text { Physical facilities and online banking of the bank I use are visually } \\
\text { appealing. }\end{array}$ \\
\hline & P3 & $\begin{array}{l}\text { The employees of the bank I use are well-dressed and neat in their } \\
\text { appearance. }\end{array}$ \\
\hline & P4 & $\begin{array}{l}\text { The appearance of the physical facilities of the bank I use is in keeping } \\
\text { with the type of services provided. }\end{array}$ \\
\hline \multirow{5}{*}{ Reliability } & P5 & $\begin{array}{l}\text { When the bank I use promises to do something by a certain time, it } \\
\text { does so. }\end{array}$ \\
\hline & P6 & $\begin{array}{l}\text { When customers have problems, the bank I use is sympathetic and } \\
\text { reassuring. }\end{array}$ \\
\hline & P7 & The bank I use is dependable. \\
\hline & P8 & The bank I use provides its services at the time it promises to do so. \\
\hline & P9 & The bank I use keeps its records accurately. \\
\hline \multirow{4}{*}{ Responsiveness } & P10 & $\begin{array}{l}\text { The bank I use is expected to tell customers exactly when services will } \\
\text { be performed. }\end{array}$ \\
\hline & P11 & $\begin{array}{l}\text { The employees of the bank I use really give prompt service to } \\
\text { customers. }\end{array}$ \\
\hline & P12 & $\begin{array}{l}\text { The employees of the bank I use always have to be willing to help } \\
\text { customers. }\end{array}$ \\
\hline & P13 & $\begin{array}{l}\text { It is okay to the bank I use to respond to customer requests promptly } \\
\text { even if it is too busy. }\end{array}$ \\
\hline \multirow{4}{*}{ Assurance } & P14 & Customers can trust the employees of the bank I use. \\
\hline & P15 & $\begin{array}{l}\text { Customers can feel safe in their transactions with the employees of } \\
\text { the bank I use. }\end{array}$ \\
\hline & P16 & The employees of the bank I use are polite. \\
\hline & P17 & $\begin{array}{l}\text { The employees of the bank I use get adequate support from the bank } \\
\text { to do their jobs well. }\end{array}$ \\
\hline \multirow{5}{*}{ Empathy } & P18 & The bank I use gives customers individual attention. \\
\hline & P19 & The bank I use has employees who give customers personal service. \\
\hline & P20 & $\begin{array}{l}\text { The employees of the bank I use really know the specific needs of its } \\
\text { customers. }\end{array}$ \\
\hline & P21 & The bank I use really has its customers' best interests at heart. \\
\hline & P22 & $\begin{array}{l}\text { The bank I use is expected to have operating hours that are } \\
\text { convenient to all its customers. }\end{array}$ \\
\hline
\end{tabular}

